\title{
Nursing Now and the role of nursing in the context of pandemic and current work
}

\author{
Nursing Now e o papel da enfermagem no contexto da pandemia e do trabalho atual \\ Nursing Now y el rol de la enfermería en el contexto del trabajo pandémico y actual
}

How to cite this article:

Oliveira KKD, Freitas RJM, Araújo IL, Gomes JGN. Nursing Now and the role of nursing in the context of pandemic and current work. Rev Gaúcha Enferm. 2021:42(spe):e20200120 doi: https://doi.org/10.1590/19831447.2021 .20200120
- Universidade do Estado do Rio Grande do Norte (UERN), Departamento de Enfermagem. Pau dos Ferros, Rio Grande do Norte, Brasil.

\section{Kalyane Kelly Duarte de Oliveira ${ }^{a}$ Rodrigo Jácob Moreira de Freitas ${ }^{a}$ Janieiry Lima de Araújo ${ }^{a}$ José Giovani Nobre Gomes ${ }^{\mathrm{a}}$}

\section{ABSTRACT}

Objective: To discuss the Nursing Now Campaign and the role of Nursing in times of pandemic by COVID-19.

Method: This is a theoretical reflection based on the scientific literature.

Results: The pandemic highlights the importance of Nursing care for the maintenance of life and the right to health, and the Nursing Now Campaign is in line with the call for appreciation of nursing professionals currently working at the forefront of the fight against COVID-19. Despite the limitations of structural resources that lead to exposure to illness, nursing professionals maintain their role of caring.

Conclusion: It is necessary for Nursing to recognize its own value, add to its continuous learning capacity, and be aware of the social changes that occur. The study contributes to rethinking strategies for valuing Nursing.

Keywords: Nursing. Pandemics. Nurse's role. Occupational health. Nurse practitioners.

\section{RESUMO}

Objetivo: Discutir sobre a Campanha Nursing Now e o papel da enfermagem em tempos de pandemia por COVID-19.

Método: Trata-se de uma reflexão teórica baseada na literatura científica.

Resultados: A pandemia evidencia a importância dos cuidados de Enfermagem para a manutenção da vida e o direito à saúde e a Campanha Nursing Now coaduna com o chamado para valorização dos profissionais de enfermagem que hoje atuam na linha de frente do combate ao COVID-19. Apesar das limitações de recursos estruturais que leva a exposição ao adoecimento, os profissionais de enfermagem mantêm o seu protagonismo de cuidar.

Conclusão: É necessário que a Enfermagem reconheça seu próprio valor, atice a sua capacidade contínua de aprendizado e tenha consciência das mudanças sociais que ocorrem. 0 estudo contribui para repensar estratégias de valorização da enfermagem como imprescindível para superar os desafios que o século XXI nos apresenta.

Palavras-chave: Enfermagem. Pandemias. Papel do profissional de enfermagem. Saúde do trabalhador. Profissionais de enfermagem.

\section{RESUMEN}

Objetivo: Debatir la Campaña Nursing Now (Enfermería Ahora) y rol de la Enfermería en tiempos de pandemia por COVID-19.

Método: Esta es una reflexión basada en la literatura cientííca.

Resultados: La pandemia destaca la importancia de la atención de Enfermería para el mantenimiento de la vida y del derecho a la salud, y la Campaña Nursing Now se condice con el llamado a la apreciación de los profesionales de Enfermería que hoy trabajan a la vanguardia de lucha contra el COVID-19. A pesar de las limitaciones de recursos estructurales que conducen a la exposición a enfermedades, los profesionales de Enfermería mantienen su función de atención de la salud.

Conclusión: Es necesario que la Enfermería reconozca su propio valor, aumente su capacidad de aprendizaje continuo y esté al tanto de los cambios sociales que ocurren. El estudio contribuye a repensar estrategias para valorar la Enfermería. Palabras clave: Enfermería. Pandemias. Rol de la Enfermería. Salud laboral. Enfermeras practicantes. 


\section{IINTRODUCTION}

In February 2018, the International Nurses Council (INC), the World Health Organization (WHO), and the British All Party Parliamentary Group on Global Health launched the Nursing Now Campaign, as a strategy for the empowerment of nursing professionals adhered to by 30 countries $^{(1)}$. In Brazil, it is carried out by the Federal Nursing Council (Conselho Federal de Enfermagem, COFEn) in partnership with the WHO Collaborating Center for the Development of Nursing Research linked to the University of São Paulo/ Ribeirão Preto. The main objective of Nursing Now Brazil is to present the nursing professionals as the real protagonists of Brazilian health ${ }^{(2-3)}$.

It is known that Nursing acts from health promotion to the hospital front line and at the several care levels. However, with the reality imposed by the SARS-CoV-2 pandemic, at the same time that the importance of the nursing role was highlighted by the media, the situations of illness and life risks resulting from COVID-19 exposed the general population to precarious working conditions to which health workers are exposed.

The existing problem of devaluation of the nursing work is not current; however, during the pandemic, it is perceived that it goes through issues of the worker's own health and reflects on patient safety, since the current working conditions bring illness to the professionals, inadequate functioning of the care services, and difficulty in protecting the patients. Thus, valuing nursing work directly reflects on the quality of the health services provided.

Thus, the question is: How will the Nursing Now Campaign achieve the goals foreseen for the professional valuation of Nursing in this chaotic and uncertain context? The research is justified by the need for reflections on the valuation of Nursing in this period of crisis, since these professionals correspond to $50 \%$ of all the health workers and face unsatisfactory working conditions; low wages; and insufficient human and material resources to serve the population that knocks on the doors of the services and does not find resoluteness. In this way, Nursing acts with "juggling" to keep up to date, to propose innovations, maintaining an ethical posture in the face of the responsibility that is given to them by profession(4).

This is a theoretical reflection based on scientific publications on the role of Nursing, on the Nursing Now Campaign, and on the fight against the coronavirus. Thus, the objective is to discuss the Nursing Now Campaign and the role of Nursing in times of pandemic by COVID-19.
To such an end, the text will be presented in two moments, a priori, a discussion about the protagonism of Florence Nightingale and the birth of Modern Nursing, and a posteriori, specifically, the pandemic currently experienced and the conditions of work and precariousness to which Brazilian Nursing has been exposed, opposing them to the international debate on valuing the profession based on the Nursing Now Campaign.

\section{YEARS OF FLORENCE NIGHTINGALE AND THE ROLE OF NURSING IN THE CONTEXT OF THE SARS-COV-2 PANDEMIC}

The choice of 2020 as the International Year of Nursing is not by chance, it is an allusion to the bicentenary of Florence Nightingale's (1820-1910) birth, the precursor of Modern Nursing. The care actions implemented by Florence aimed at raising the bar of the sanitary conditions of the hospital environment, adopting hygiene measures and direct care for soldiers injured in battle ${ }^{(5-6)}$. The legacy left by Nightingale is immeasurable and spans the centuries to guide and support Nursing worldwide.

The revolutionary ideas on the hospital reform were published in 1859 and presented the previous year in the Social Science Congress. Nightingale developed a comprehensive view of patient care, expanding the notion of ambience and expressing the importance of hygiene assumptions: fresh air and fresh water, cleanliness, adequate drainage, and light. When caring for a patient, Nursing must consider their feelings and needs, in order to provide comfort for their full recovery ${ }^{(7)}$.

The various epidemic outbreaks experienced in this $21^{\text {st }}$ century impose for the various actors the imperative to act and dialog to effect global health and, consequently, the preservation of human life. Only in this $21^{\text {st }}$ Century, the WHO declared a public health emergency of international importance (PHEII) on the occasions of H1N1 (2009); Poliomyelitis (2014); Zika (2016), and Ebola (2014 and 2019). There were several warnings reported to the governments, leaders and health systems of the world, in order to guard against the situation that we now experience ${ }^{(5)}$.

Considering the global demographic, epidemiological, environmental, economic and social aspects that Nursing faces today, as well as the trajectory already coined by predecessors in times of public emergency, it is possible to estimate the national and international importance of Nursing in health settings and its impact on minimizing the disease, both in the world and in Brazil. 
The current pandemic moment, which imposed social isolation/distancing on humanity and awareness raising regarding changes in behavior in relation to preventive measures, such as hand washing, personal and environmental hygiene, adequate eating, access and hospital care for patients, among others, reminds us of the assumptions so defended by Florence: theoretical and practical study, discipline and management of the Nursing care are important to reestablish individual and collective health, so that the current moment requires nurses, leadership, political action, capacity for dialog and social responsibility with human life, and with the lives of the nursing professionals who are on the front line, who every day build, in the practice, a more qualified, ethical, technical and scientific"new Nursing care" for confronting COVID-19(5-6).

Thus, it is pointed out that, historically, world Nursing has always acted in times of crisis, as a protagonist on the front lines during conflicts and wars, as well as in environmental and humanitarian catastrophes. It would be no different for Nursing to echo in the global discourses as indispensable in combating epidemics, especially in the pandemic by SARSCoV-2 currently experienced, but it is necessary to think in what conditions this action takes place, in how Florence's contributions and the so-called "valuation" of Nursing materialize in the day-to-day work, and in whatever challenges the future of the pandemic will bring for the profession.

\section{THE NURSING NOW CAMPAIGN FOR NURSING IN THE CONTEXT OF THE SARS-COV-2 PANDEMIC}

In view of the goals established by the Nursing Now Brazil Campaign ${ }^{(3)}$, such as investing in strengthening the education and development of the nursing professionals with a focus on leadership; investing in improving the working conditions of the nursing professionals; and disseminating effective and innovative nursing practices based on scientific evidence, at national and regional levels; its importance to urgent needs becomes evident, especially at a time of the COVID-19 pandemic, which has highlighted the weaknesses of the organization of the Nursing services and working conditions.

The Nursing Now Campaign takes on disturbing themes that concern Nursing, linked to teaching, practice and research. These remain current in view of the other problems experienced by the category: insufficiency of professionals according to the dimension needed to perform Nursing care; subwages; precarious working conditions; devaluation of the nurse's work; difficulty in recruiting professionals and students; staff retention; and flight of researchers. Additionally, questions arise that enhance the theme, such as: gender; withdrawal of labor rights; violence and moral and sexual harassment; overload and work wear out; and precariousness in the training and qualification of human resources ${ }^{(4)}$.

At the national level, we have a long road ahead to strengthen the articulation between the educational institutions and the health services in order to meet the goals of the Nursing Now Campaign. It is necessary to invest in the workforce and in the valuation of the teaching professional; improve training and, mainly, work, in conjunction with services, to advance the profession. This is the current professional paradox because, while the valuation of Nursing is discussed, the past challenges dialog with the present and bring us the uncertainties of a near future ${ }^{(8)}$.

An example of this is the auguries of the reality in Brazil, at the same time that the COFEn seeks to qualify professionals, support research studies through professional master's degrees, in partnership with the Coordination for the Improvement of Higher Level Personnel (Coordenação de Aperfeiçoamento de Pessoal de Nível Superior, CAPES), directed to the theme of Nursing Care Systematization (NCS), since 2016, the performance of other class councils is observed, investing in lawsuits against the autonomy of Nursing, as established by the Law of Professional Nursing Practice (1986). Thus, the various advances of the Federal Council of Medicine (Conselho Federal de Medicina, CFM) are cited as an example to limit Nursing duties; as well as the Federal Council of Physiotherapy (Conselho Federal de Fisioterapia, CREFITO) that fights to retain the care of wounds and dressings for itself(9).

In the midst of these advances, Nursing continues in the struggle to conquer its space of autonomy, seeking to establish itself as a science by developing research studies that will subsidize the practice by means of its own body of knowledge; for this, it seeks interlocution with other areas of knowledge. In this context, we witness an expansion of evidence-based research studies, a substantial growth in clinical studies and in the number of professionals with master's, doctoral and post-doctoral courses ${ }^{(9)}$.

First of all, self-value is the most important aspect. The profession must not lose sight of attributes that are specific to it, such as presence at the moment, listening and caring. Values that cannot be minimized or forgotten because, although other professions and the use of technologies also provide health and care, only nurses can be the voice of deeper human needs ${ }^{(8)}$.

Global health institutions are aware that Nursing care is essential for the efforts to prevent and respond to COVID-19. Nursing is the largest health professional category with more than 20 million nurses worldwide, who continue to provide care in the context of the SARS-CoV-2 pandemic, from the 
screening of suspected cases, collection of material for exams, guidelines for isolation until the execution of hospital care resulting from the complications of COVID-19, in addition to acting in health education, administration and management, teaching and research actions ${ }^{(10)}$.

Nurses are already fully engaged and, if they receive the appropriate support, they will be the protagonists in this battle ${ }^{(10)}$. The Nursing workforce is expanding in size and professional scope. However, the expansion is not fair, it is insufficient to meet the growing demand. There are significant gaps in data on educational capacity, financing, wages and the work market ${ }^{(5)}$.

In scenarios with weakened working conditions and with insufficient supplies and protective equipment, nurses are faced with a series of personal and professional challenges, having to deal with the risk of illness of their team, the fear of their own death and of their colleagues, increased working hours, and the complexity of the work imposed by the clinical management of COVID-19(5). Despite these conditions, these professionals demonstrated resilience and ethical commitment to continue providing Nursing care.

It is urgent to consider that the valuation of Nursing and the changes in the working conditions of these professionals contributed to a better comprehensive care, to healthier relationships with the multidisciplinary work team, ensuring patient safety, and better progress of the public policies, strengthening of the Unified Health System and, consequently, democracy. With this, in view of the challenges of the current work, it is necessary for Nursing to acknowledge its own value, redefine its professional role, strengthen its continuous learning capacity, and be aware of the epidemiological, demographic, social, political and economic changes that the world is going through.

\section{aINAL CONSIDERATIONS}

For Nursing, the year 2020 will once again leave our value and importance in the historical conscience. Nowadays, the Nursing Now Campaign continues to show the world the value of Nursing care when designing theoretical constructs for confronting the COVID-19 pandemic in the daily practice. However, despite the expressive number of professionals and the space they occupy, and despite the current valuation campaign, Nursing is still called upon to justify its existence as a necessary professional area for society.
Thus, the Nursing of the present and of the future will value human nature to the detriment of the apparatus of the technologies, avoiding the mechanization of care and expanding the Nursing Process to care for individuals, workers, families and communities. Thus, Nursing has built its professional role over the centuries, we are care professionals indispensable for human life in society.

With that, the study contributes to rethinking strategies for valuing Nursing in the various fields of performance, be it in teaching, research, assistance or management, and the need for us to listening again to precursor Florence, but with a critical and reflective eye on her teachings, in the sense of rewriting "what is Nursing and what is not Nursing", a social practice, based on science, ethics and political action, as well as an indispensable health practice to overcome the challenges that the $21^{\text {st }}$ century presents us.

\section{REFERENCES}

1. Crisp N, Iro E. Nursing Now campaign: raising the status of nurses. Lancet. 2018 [cited 2020 Apr 13];391(10124):920-1. Available from: https:// www.thelancet.com/journals/lancet/article/PIIS0140-6736(18)30494-X/ fulltext

2. Bortoli CSH, Garcia LNJC. Nursing perspectives and the "Nursing Now" Campaign. Rev Bras Enferm. 2018 [cited 2020 Apr 15];71(5):2351-2. Available from: http:// www.scielo.br/pdf/reben/v71n5/0034-7167-reben-71-05-2351.pdf

3. Nursingnowbrorg [Internet]. Campanha Nursing Now: Onde há vida, há enfermagem. 2020 [cited 2020 Apr 16]. Available from: http:// nursingnowbr.org/

4. Angerami ELS. Nursing: dialogue with the past in the commitment to the present. Rev Latino-Am Enfermagem. 2019 [cited 2020 Apr 14];27: e3220. Available from: http://www.scielo.br/pdf/rlae/v27/0104-1169-rlae27-e3220.pdf

5. World Health Organization (CH). State of the world's nursing 2020: investing in education, jobs and leadrship. 2020 [cited 2020 Apr 16]. Available from: https://www.who.int/publications-detail/nursing-report-2020

6. Nightingale F. Notes nursing: a guide for today's caregivers [updated]. International Council of Nurses, editor. Edinburgh, New York: Elsevier/Baillière Tindall; 2010.

7. Bezerra $C M B$, Silva $B C O$, Silva RAR, Martino MMF, Monteiro Al, Enders $B C$. Análise descritiva da teoria ambientalista de enfermagem. Enferm Foco. 2018 [cited 2020 Apr 15];9(2):79-83. Available from: http://revista.cofen.gov.br/ index.php/enfermagem/article/view/1105

8. Fernandes MNF, Esteves RB, Teixeira CAB, Gherardi-Donato ECS. The present and the future of Nursing in the Brave New World. Rev Esc Enferm USP. 2018 [cited 2020 Apr 13];52:e03356. Available from: http://www.scielo.br/pdf/reeusp/ v52/en_1980-220X-reeusp-52-e03356.pdf 
9. Oliveira TBRG, Itayara PM, Lucas BK. The euphemism of good practice or advanced nursing practice. Esc Anna Nery. 2019 [cited 2020 Apr 14];23(3):e20180385. Available from: http://www.scielo.br/pdf/ean/ v23n3/1414-8145-ean-23-03-e20180385.pdf

\section{- Corresponding author:}

Rodrigo Jácob Moreira de Freitas

E-mail: rodrigojmf@gmail.com
10. Choi KR, Skrine JK, Logsdon MC. Nursing and the Novel Coronavirus: risks and responsibilities in a global outbreak [editorial]. J Adv Nurs. 2020;76(7): 1486-7. doi: https://doi.org/10.1111/jan.14369

\section{Associate editor:}

Dagmar Elaine Kaiser

Editor-in-chief:

Approved: 07.13.2020

Maria da Graça Oliveira Crossetti 